\title{
Ultrasonographic and Vaginal Cytological Diagnostics of the Queen
}

\author{
Pertiwi $\mathrm{AP}^{1}$, Tumbelaka LITA², Ulum $\mathrm{MF}^{2}$ \\ ${ }^{1}$ Profesional Education Program for Doctor of Veterinary Medicine, Faculty of Veterinary Medicine, Bogor Agricultural University, Jalan \\ Agatis Kampus IPB Dramaga, Bogor, Jawa Barat 16680, Indonesia \\ ${ }^{2}$ Department of Clinic Reproduction and Pathology, Faculty of Veterinary Medicine, Bogor Agricultural University, Jalan Agatis Kampus IPB \\ Dramaga, Bogor, Jawa Barat 16680, Indonesia \\ E-mail: ulum@ipb.ac.id
}

(received 01-04-2018; revised 27-06-2018; accepted 23-08-2018)

\begin{abstract}
ABSTRAK
Pertiwi AP, Tumbelaka LITA, Ulum MF. 2018. Ultrasonografi dan diagnosa sitologi vagina dari kucing betina. JITV 23(3): 130-142. DOI: http://dx.doi.org/10.14334/jitv.v23i3.1809

Ultrasonografi adalah metode diagnosis untuk mencitrakan struktur organ reproduksi, dan hal ini harus didukung oleh sitologi vagina untuk mengidentifikasi aktivitas ovarium berdasarkan jenis sel epitel vagina. Tujuan dari penelitian ini adalah untuk mengobservasi tampilan organ reproduksi kucing betina yang didukung dengan pemeriksaan sitologi vagina. Kucing betina sebanyak 10 ekor digunakan dalam penelitian ini yang dikelompokkan berdasarkan anamnesis dan sejarah medis sebagai kelompok intact $(n=5)$ dan yang telah diovariohisterektomi $(\mathrm{OH})(\mathrm{n}=5)$. Vagina, serviks, korpus dan kornua uterus, serta ovarium dicitrakan dan diukur menggunakan ultrasonografi. Vagina, korpus dan kornua uterus tampak sebagai struktur seperti pipa dengan garis luar yang hiperekoik. Lumen pada korpus dan kornua uterus terlihat hiperekoik. Ovarium terlihat sebagai struktur berbentuk bulat atau oval dengan folikel yang anekoik. Korpus luteum berdinding tebal dan terlihat anekoik pada bagian pusatnya. Korpus albikan terlihat sebagai struktur hiperekoik. Vagina kucing betina OH terlihat berukuran lebih pendek daripada kucing betina intact. Serviks terlihat sebagai struktur hiperekoik yang menghubungkan vagina dan korpus uterus. Jenis-jenis sel epitel vagina juga diidentifikasi dan dihitung. Hasil sitologi vagina menunjukkan beberapa status aktivitas yang berbeda pada ovarium. Proestrus teridentifikasi pada 3 kucing intact, metestrus akhir pada 2 kucing intact dan 4 kucing OH, serta anestrus pada 1 kucing $\mathrm{OH}$. Morfologi uterus dan servik juga dipengaruhi oleh aktifitas ovarium.
\end{abstract}

Kata Kunci: Status Estrus, Kucing Betina, Organ Reproduksi, Ultrasonografi, Sitologi Vagina

\section{ABSTRACT}

Pertiwi AP, Tumbelaka LITA, Ulum MF. 2018 Ultrasonographic and vaginal cytological diagnostics of the Queen. JITV 23(3): 130-142. DOI: http://dx.doi.org/10.14334/jitv.v23i3.1809

Ultrasonography is a diagnostic method to image the conditions of reproductive organs and it could be supported by vaginal cytology to identify the activities of the ovaries by the types of vaginal exfoliate cells. The aims of this study was to observe reproduction organ through ultrasonography with supportive diagnostic with vaginal cytological assessment. A total of 10 individual queens were used in this study and then grouped into intact group $(n=5)$ and spayed (ovariohysterectomy) group ( $\mathrm{n}=5$ ) based on the anamneses or their medical history. The vagina, cervix, uterus body and horns, and ovaries were imaged and measured by ultrasound. Vagina, uterine body and horn seem as pipe-like structures with hyperechoic outer lines. The lumen in uterine body and horn seem as a hyperechoic structure. The ovaries seem as round- or oval-shaped structures with anechoic follicles. The corpus luteal has thick wall and seen as anechoic in its centre part. The corpus albicans seems as a hyperechoic structure. The vagina of spayed queens seemed more corrugated than those intact queens. The cervix is seen as a hyperechoic structure linking the vagina and uterine body. Exfoliate vaginal epithelial cell types were then also be identified and counted on each queens. The results of vaginal cytology showed that proestrus occured in 3 intact queens, late metestrus in 1 intact and 3 spayed queens, anestrus in 1 spayed queen, and unidentifiable estrus stage in 1 intact and 1 spayed queens. Moreover, the morphology of cervix and uterine was affected by the activity of ovary.

Key Words: Estrus State, Queen, Reproductive Organs, Ultrasonography, Vaginal Cytology

\section{INTRODUCTION}

The importance of reproductive organ ultrasonography in diagnosing estrus state in queen such as estrus or estrus disorder, is well established and documented (Davidson \& Baker 2009; Malandain et al. 2011). The indicators evaluated are size of uterine wall tissue and size of ovary including follicles, corpus luteum, and other ovarian tissues in an intact queen. However, spayed queens in several case has been reported shows a sign of estrus that in ultrasonography examination was not find the ovary. This condition was knows as ovary remnant syndrome (ORS) (Wallace 1991) that cannot independently assessed by vaginal 
cytology (Mills et al. 1979). Even though the diagnostic of ultrasonography cannot image the systemic status of reproductive status, it is valuable diagnostic tool to image internal architecture of reproductive organ tissue, locally. Ultrasound imaging nowadays is used to assess the reproductive organ in several species in Indonesia, such as cat and dog (Noviana et al. 2012), kacang goat (Santoso et al. 2014), garut sheep (Amrozi \& Setiawan 2011; Gunawan et al. 2012), horse (Rahman 2012), also timor deer (Prawigit 2007), tom (Ulum et al. 2017), and phyton (Lestari et al. 2017).

Another method used in order to assess reproductive (estrus) status in systemic state indirectly, vaginal cytology, also well established and documented (Mattos et al. 2003; Mills et al. 1979). In this vaginal cytology examination, the presence of exfoliate vaginal cells was represented the systemic status of reproductive organ activity. This method can determine the stage of oestrus cycle, endocrine and reproduction pathology indirectly in animals (Mattos et al. 2003). This is caused by the high responsivity of vaginal epithelial cells towards hormone fluctuation, especially estrogen which will causing changes of vaginal cellular profiles (ErünalMaral et al. 2000). The use of vaginal cytology in determining the stage of oestrous cycle is well applied in dog (Reddy et al. 2011), Ettawa grade goat (Satria et al. 2016), and javan mongoose (Zora 2014).

Although the two methods were used individually in veterinary clinical services, however, no prospective study of the subject has yet been conducted, and regard to these two methods in their ability to diagnose reproductive status in precisely. The aims of this study were to assess the mutual support between ultrasonography findings with vaginal cytological results, and to establish a logical approach concerning the presence of estrus cycle in queens. In this study, totally ten of intact and spayed queens were undergo gynecological examination by ultrasonography scanning and vaginal cytology. Sonogram of reproductive organs measurements and exfoliate vaginal cell count were compared in order to diagnose the estrus state of each queens.

\section{MATERIALS AND METHODS}

\section{Animals}

Two groups of queens used in this study were the intact queens $(n=5)$ and the spayed queens $(n=5)$. The cats were obtained from the inside and surrounding area of Bogor Agricultural University, some of them were strays and the others were owned as pet animals. The queen's age was determined by examining its body and teeth condition. Age determination was done based on the criteria made by The Humane Society of the United States (1996): at 5-7 months old, all teeth have changed into permanent teeth; at 1-2 years old, the teeth may appear dull with some tartar build-up on back teeth; at 3-5 years old, the teeth show more tartar build-up on all teeth and some tooth wear; at 10-15 years old, the teeth are worn and show heavy tartar build-up, and some teeth may be missing. Nulliparous and multiparous status were determined based on observation of the abdomen and nipple condition. Multiparous individuals have more protractile nipples than nulliparous individuals (WHO \& UNICEF 2009).

\section{Ultrasound imaging}

The queens were physically restrained without anesthesia or sedation. Abdomen hair was also not trimmed for ultrasound. Ultrasound gel (Hamco, PT Bintang Putra Pratama, Indonesia) was applied on the hypogastric area of the abdomen. Sonogram was taken using an ultrasound console (SonoDop S-3X, PT Karindo Alkestron Indonesia) with a linear transducer owing $10 \mathrm{MHz}$ of frequency in longitudinal and transversal views. The queen was positioned in dorsal recumbence and the sonogram was taken from the hypogastric part of the queen's ventral body (Figure 1).
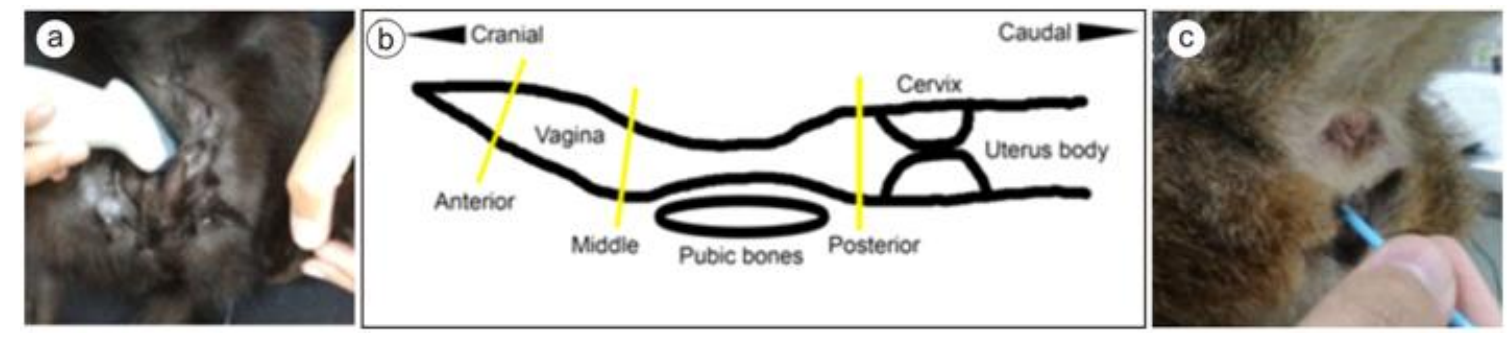

Figure 1. Ultrasonography imaging of reproductive organ and its vaginal swabbing of the queens.

The position of the transducer positioning for scanning of reproductive organ (A)

Illustration of the vaginal measurement parts (B)

The vaginal swabbing process (C). 
Measurement the size of reproductive organ was done by Image (NIH, USA) after the sonograms were saved in JPG format. Reproductive organs that assessed in sonogram of this study i.e. vagina, cervix, uterus body and horns, ovaries, corpus luteum, corpus albican, corpus rubrum, and follicles. Measurements size and number of each parts of reproductive organs were done in three repetitions. The measurements of vaginal size were done in three different spots i.e. anterior, middle, and posterior.

\section{Vaginal cytology}

The vagina of queens was the swabbed by using a cotton swab (Baby Huki, PT Ikapharmindo Putramas, Indonesia) that has been moistened with distilled water (Figure 1). The tip of the cotton swab was put into the vulva, slightly inclinated and then pushed inside gently. Swab was done by rotating the tip clockwise $2-3$ times. The tip was then smeared onto the surface of an object glass and left to dry. The vaginal smear was then fixated using methanol for 5 minutes and stained with $10 \%$ of Giemsa (Merck, PT Merck Tbk, Indonesia) for 30 minutes. The stained results were observed with light microscope (Olympus CX31, PT Fajar Mas Murni, Indonesia) using $4 \mathrm{x}, 10 \mathrm{x}$, and $40 \mathrm{x}$ of objective magnifications. Photos of microscope observation were taken using a digital microscope camera (HDMI \& USB Multioutput HD Camera Indomicro, Indonesia). The proportion of parabasal, intermediate, and superficial vaginal epithelial cells per 100 epithelial cells and neutrophils per 2 fields of view were counted to determine the stage of the estrus. Vaginal epithelial cell type determination was based on (Cowell et al. 2007; Mills et al. 1979) which categorized the cells as below: superficial epithelial cell is the biggest type with small nucleus (oval-shaped and will become picnotic and disappear later); intermediate epithelial cell is approximately two times larger than the parabasal epithelial cell, it is round- to oval-shaped with a vesicular to flattened nucleus; parabasal epithelial cell is the smallest type, with almost-similar sizes and shapes, a big vesicular nucleus and a little cytoplasm. The stage of the estrus determination was based on (Mills et al. 1979).

\section{Data analysis}

Obtained data of sonogram and its measurement were presented and descripted narratively. Exfoliate vaginal cell counting from vaginal cytology were analyzed and presented to show the estrus stage of each queens.

\section{RESULTS AND DISCUSSION}

Table 1. shows the profile of all of the queens that used in this study, which consisted of 8 Domestic cats and 2 Persian-mix cats. All queens did not show behavioral signs of estrous when the ultrasound was being done. Queens Intact 1 and 5 were multiparous, while queens Intact 2, 3, and 4 were nulliparous.

Table 1. Profile of the queens that used in the study

\begin{tabular}{lcccccc}
\hline \hline Queen ID & Race & $\begin{array}{c}\text { Status } \\
(\text { Stray/Pet })\end{array}$ & $\begin{array}{c}\text { Age } \\
(\text { months })\end{array}$ & $\begin{array}{c}\text { Weight } \\
(\mathrm{kg})\end{array}$ & $\begin{array}{c}\text { Estrus } \\
\text { Behavior }\end{array}$ & Nulliparous/Multiparous \\
\hline Intact 1 & Domestic & Stray & 20 & 3.0 & None & Multiparous \\
Intact 2 & Domestic & Pet & 14 & 2.0 & None & Nulliparous \\
Intact 3 & Domestic & Pet & 12 & 1.9 & None & Nulliparous \\
Intact 4 & Domestic & Stray & 5 & 2.0 & None & Nulliparous \\
Intact 5 & Domestic & Stray & 14 & 3.2 & None & Multiparous \\
Spayed 1 & Domestic & Stray & 24 & 3.6 & None & n.a. \\
Spayed 2 & Domestic & Pet & 8 & 4.2 & None & n.a. \\
Spayed 3 & Persian mix & Pet & 84 & 3.5 & None & n.a. \\
Spayed 4 & Persian mix & Pet & 47 & 3.7 & None & n.a. \\
Spayed 5 & Domestic & Stray & 80 & 2.8 & None & n.a. \\
\hline Intact = 5, & Domestic=8; & Pet=5; & $8-84$ & $1.9-4.2$ & None & Nulliparous=3; Multiparous=2 \\
Spayed =5 & Persian mix=2 & Stray=5 & & &
\end{tabular}

Note: n.a.=not available, where the nulliparous/multiparous status was not determined in spayed queens 


\section{Sonogram of vagina and cervix}

Sonogram of vagina was seen as an anechoic pipelike structure with hyperechoic walls that narrowed caudally (Figure 2). Table 2 shows the measurement results of vagina and cervix. Measurement of spayed queen vagina was done only at the front and the middle parts of the vagina. The average diameter of the front part of intact queen's vagina $(2.58 \pm 0.26 \mathrm{~mm})$ was smaller than the spayed ones $(4.02 \pm 0.64 \mathrm{~mm})$.
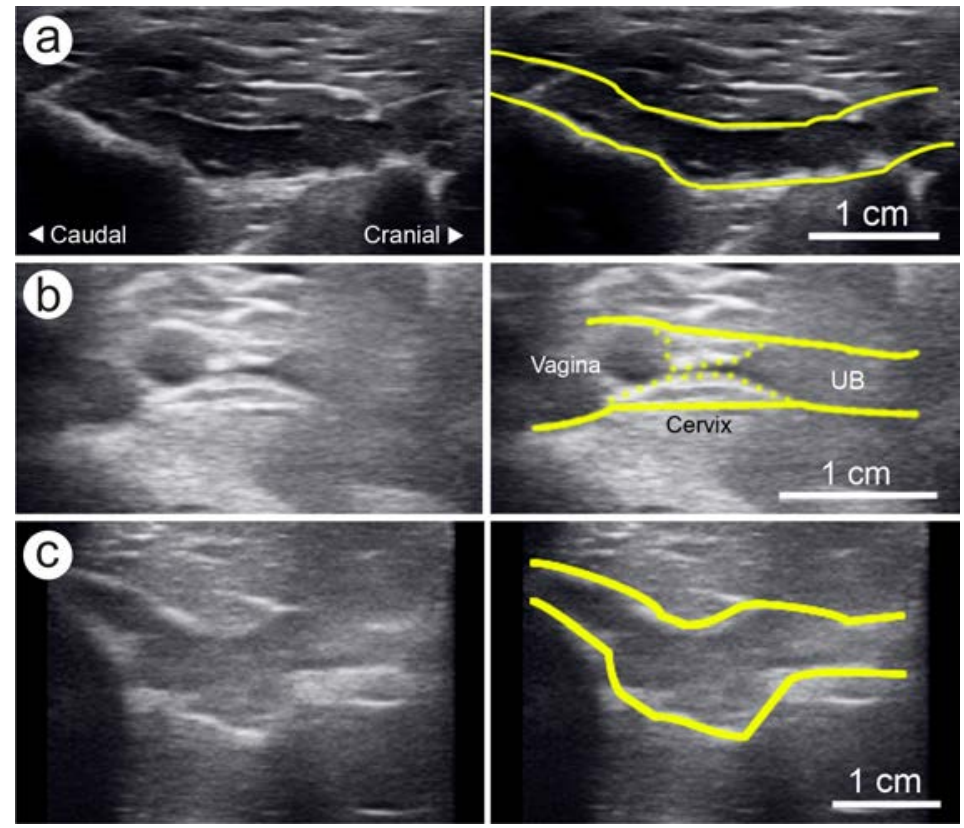

Figure 2. Sonograms of vagina, cervix, and uterine body of the queens. Sonograms of vagina queen Intact 1 (a), vagina of queen Spayed 1 (b), and vagina, cervix, and uterus body (UB) of queen Intact 1 (c). Cervix (interrupted lines) seems hyperechoic, and located between the vagina and the uterus body.

Table 2. Size of vagina and cervix of the queens

\begin{tabular}{|c|c|c|c|c|c|c|c|}
\hline \multirow[b]{2}{*}{ Queen ID } & \multicolumn{3}{|c|}{ Vagina } & \multicolumn{4}{|c|}{ Cervix } \\
\hline & $\begin{array}{c}\text { Diameter of } \\
\text { anterior (mm) }\end{array}$ & $\begin{array}{l}\text { Diameter of } \\
\text { middle (mm) }\end{array}$ & $\begin{array}{c}\text { Diameter of } \\
\text { posterior }(\mathrm{mm})\end{array}$ & $\begin{array}{l}\text { Length } \\
(\mathrm{mm})\end{array}$ & $\begin{array}{l}\text { Diameter } \\
\text { (mm) }\end{array}$ & $\begin{array}{c}\text { Thickness of } \\
\text { ventral layer } \\
(\mathrm{mm})\end{array}$ & $\begin{array}{c}\text { Thickness of } \\
\text { dorsal layer } \\
(\mathrm{mm})\end{array}$ \\
\hline Intact 1 & $2.96 \pm 0.56$ & $4.48 \pm 0.29$ & $3.79 \pm 0.07$ & $5.36 \pm 0.37$ & $4.14 \pm 0.04$ & $1.88 \pm 0.35$ & $1.74 \pm 0.25$ \\
\hline Intact 2 & $2.32 \pm 0.37$ & $3.63 \pm 0.09$ & $2.33 \pm 0.06$ & $5.81 \pm 0.49$ & $2.58 \pm 0.11$ & $1.15 \pm 0.27$ & $1.05 \pm 0.12$ \\
\hline Intact 3 & $2.71 \pm 0.18$ & $4.01 \pm 0.33$ & $3.00 \pm 0.15$ & $3.75 \pm 0.29$ & $2.77 \pm 0.10$ & $0.63 \pm 0.12$ & $1.23 \pm 0.15$ \\
\hline Intact 4 & $2.40 \pm 0.25$ & $3.20 \pm 0.21$ & $3.73 \pm 0.32$ & $5.83 \pm 0.11$ & $2.93 \pm 0.08$ & $0.63 \pm 0.19$ & $1.75 \pm 0.17$ \\
\hline Intact 5 & $2.50 \pm 0.44$ & $4.80 \pm 0.13$ & $6.36 \pm 0.15$ & $10.22 \pm 0.54$ & $5.89 \pm 0.17$ & $2.65 \pm 0.12$ & $2.36 \pm 0.08$ \\
\hline Mean intact & $2.58 \pm 0.26$ & $4.02 \pm 0.64$ & $3.84 \pm 1.53$ & $6.19 \pm 2.41$ & $3.66 \pm 1.39$ & $1.39 \pm 0.87$ & $1.63 \pm 0.51$ \\
\hline Spayed 1 & $3.09 \pm 0.38$ & $4.70 \pm 0.35$ & - & - & - & - & - \\
\hline Spayed 2 & $3.32 \pm 0.24$ & $3.81 \pm 0.33$ & - & - & - & - & - \\
\hline Spayed 3 & $3.76 \pm 0.12$ & $5.74 \pm 0.72$ & - & - & - & - & - \\
\hline Spayed 4 & $4.04 \pm 0.28$ & $4.36 \pm 0.21$ & - & - & - & - & - \\
\hline Spayed 5 & $3.01 \pm 0.39$ & $4.74 \pm 0.18$ & - & - & - & - & - \\
\hline Mean spayed & $3.44 \pm 0.44$ & $4.67 \pm 0.70$ & - & - & - & - & - \\
\hline
\end{tabular}


The average diameter of the middle part of intact queen's vagina $(4.02 \pm 0.64 \mathrm{~mm})$ was also smaller than the spayed ones $(4.67 \pm 0.70 \mathrm{~mm})$, but the front part of intact queen's vagina $(2.58 \pm 0.26 \mathrm{~mm})$ was smaller than the spayed ones $(3.44 \pm 0.44 \mathrm{~mm})$. The average diameter of the back part of spayed queen's vagina was $3.84 \pm 1.53 \mathrm{~mm}$. The spayed queens’ vagina was seemed shorter, while the intact queens' are straighter to the cranial (Figure 2). The average diameter of the five intact queens' cervix was $3.66 \pm 1.39 \mathrm{~mm}$ (Table 2 ). The cervix diameter of queens Intact 1 and 5 were larger than queens Intact 2, 3, and 4. The largest cervix was showed at queen Intact 5 . The cervix is located between the vagina and the uterus and it's seemed as a hyperechoic structure with anechoic lumen (Figure 2).

\section{Sonogram of uterine body and horns}

Sonogram in Figure 3 shows the appearance of the uterine horns with lumen and without lumen. Uterus seems as an anechoic pipe-like structure with anechoic walls and lumen. The uterus of queen Intact 5 seems thicker than other intact queens. Uterus's outer layer (serosa) and lumen seem hyperechoic. The lumen of the uterus body was only seen in queen Intact 2, 3, and 4. The lumen of the uterus body was seen in all the intact queens. The average diameter of all the intact queens' uterus bodies and horns are $4.67 \pm 1.82 \mathrm{~mm}$ and 3.76 $\pm 1.27 \mathrm{~mm}$ (Table 3).
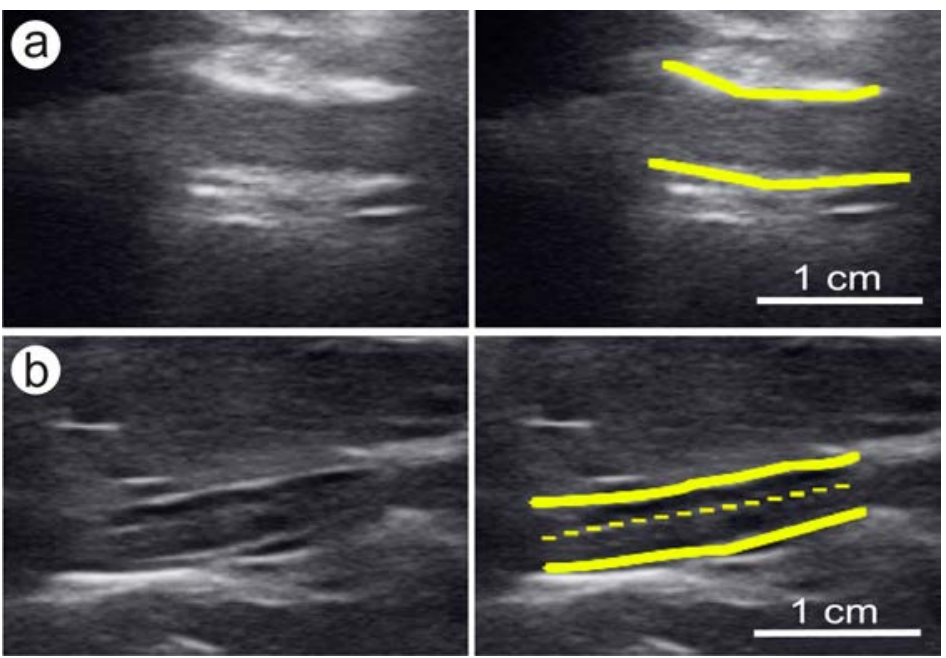

Figure 3. Sonograms of the uterine horn of the queens. The uterine horn without lumen (a) of queen Intact 1 and the uterine horn with lumen (b) of queen Intact 3. The lumen is indicated with interrupted line.

Table 3. Size of the uterus body and horn of the intact queens

\begin{tabular}{|c|c|c|c|c|c|c|}
\hline \multirow[b]{2}{*}{ Queen ID } & \multicolumn{3}{|c|}{ Uterus body } & \multicolumn{3}{|c|}{ Uterus horn } \\
\hline & $\begin{array}{l}\text { Diameter } \\
\text { (mm) }\end{array}$ & $\begin{array}{c}\text { Thickness of } \\
\text { ventral layer } \\
(\mathrm{mm})\end{array}$ & $\begin{array}{c}\text { Thickness of } \\
\text { dorsal layer (mm) }\end{array}$ & $\begin{array}{l}\text { Diameter } \\
(\mathrm{mm})\end{array}$ & $\begin{array}{c}\text { Thickness of } \\
\text { ventral layer } \\
\text { (mm) }\end{array}$ & $\begin{array}{c}\text { Thickness of } \\
\text { dorsal layer (mm) }\end{array}$ \\
\hline Intact 1 & $3.99 \pm 0.16$ & n.a. & n.a. & $3.69 \pm 0.27$ & $1.54 \pm 0.31$ & $1.71 \pm 0.04$ \\
\hline Intact 2 & $3.30 \pm 0.39$ & $1.25 \pm 0.07$ & $1.92 \pm 0.11$ & $2.61 \pm 0.01$ & $0.80 \pm 0.05$ & $1.74 \pm 0.10$ \\
\hline Intact 3 & $2.84 \pm 0.08$ & $0.70 \pm 0.09$ & $1.61 \pm 0.21$ & $3.07 \pm 0.31$ & $0.95 \pm 0.14$ & $1.63 \pm 0.02$ \\
\hline Intact 4 & $6.77 \pm 0.23$ & $2.65 \pm 0.14$ & $3.07 \pm 0.06$ & $3.53 \pm 0.11$ & $1.48 \pm 0.08$ & $1.18 \pm 0.13$ \\
\hline Intact 5 & $6.44 \pm 0.34$ & n.a. & n.a. & $5.92 \pm 0.21$ & $2.58 \pm 0.08$ & $2.80 \pm 0.00$ \\
\hline Mean intact & $4.67 \pm 1.82$ & $1.53 \pm 1.01$ & $2.20 \pm 0.77$ & $3.76 \pm 1.27$ & $1.47 \pm 0.70$ & $1.81 \pm 0.60$ \\
\hline
\end{tabular}

Note: n.a.= not available, not seen in sonogram clearly 


\section{Sonogram ovary}

Figure 4 shows the sonogram of intact queen's ovary. The shape of ovary's body is oval or round and seen as hypoechoic structure. The size of ovary, follicles, and its corpora body were measured and shown in Table 4. The largest ovary was the right ovary of queen Intact 4 whose diameter was $17.32 \mathrm{~mm}$, while the smallest one is the right ovary of queen Intact 2 whose diameter was $9.17 \mathrm{~mm}$. Sonogram of follicles seem as anechoic, corpus luteum seems hypoechoic, corpus albicans seem hyperechoic, and corpus rubrum seem as round structure with anechoic centre. The follicles were varied in size, from the largest one with $5.82 \mathrm{~mm}$ diameter in the right ovary of queen Intact 5 to the smallest one with $2.21 \mathrm{~mm}$ diameter in the right ovary of queen Intact 1 . Queen Intact 1 had the highest total of follicles, with 5 follicles: 3 in the right ovary and 2 in the left ovary. The highest total of luteal body was found in queen Intact 1 owing 6 corpus luteum. Queen Intact 4 had a corpus albicans in the right ovary and a corpus rubrum in the left ovary.

\section{Vaginal cytology}

The shape of vaginal epithelial cells and neutrophils can be seen in Figure 5 and then the results of vaginal smear cell counting were shows at Table 5 . The count of vaginal cytology at queen Intact 1 shows that the almost-similar amounts of parabasal and intermediate epithelial cells, with a moderate amount of superficial epithelial cells. The vaginal cytology count of queens Intact 2 and Spayed 2, 3, 5 show the almost similar amounts of parabasal and intermediate epithelial cells, with a few of superficial epithelial cells. The vaginal cytology count of queen Intact 3, 4, and 5 is dominated by the amount of the intermediate epithelial cells, with almost-similar amounts of parabasal and superficial epithelial cells. The amount of intermediate cells is really dominant in vaginal smear of queen Spayed 4. The highest amount of neutrophils was found in queen Intact 1. A metestrum cell was found in vaginal smear of queen Intact 4 (Figure 5d).
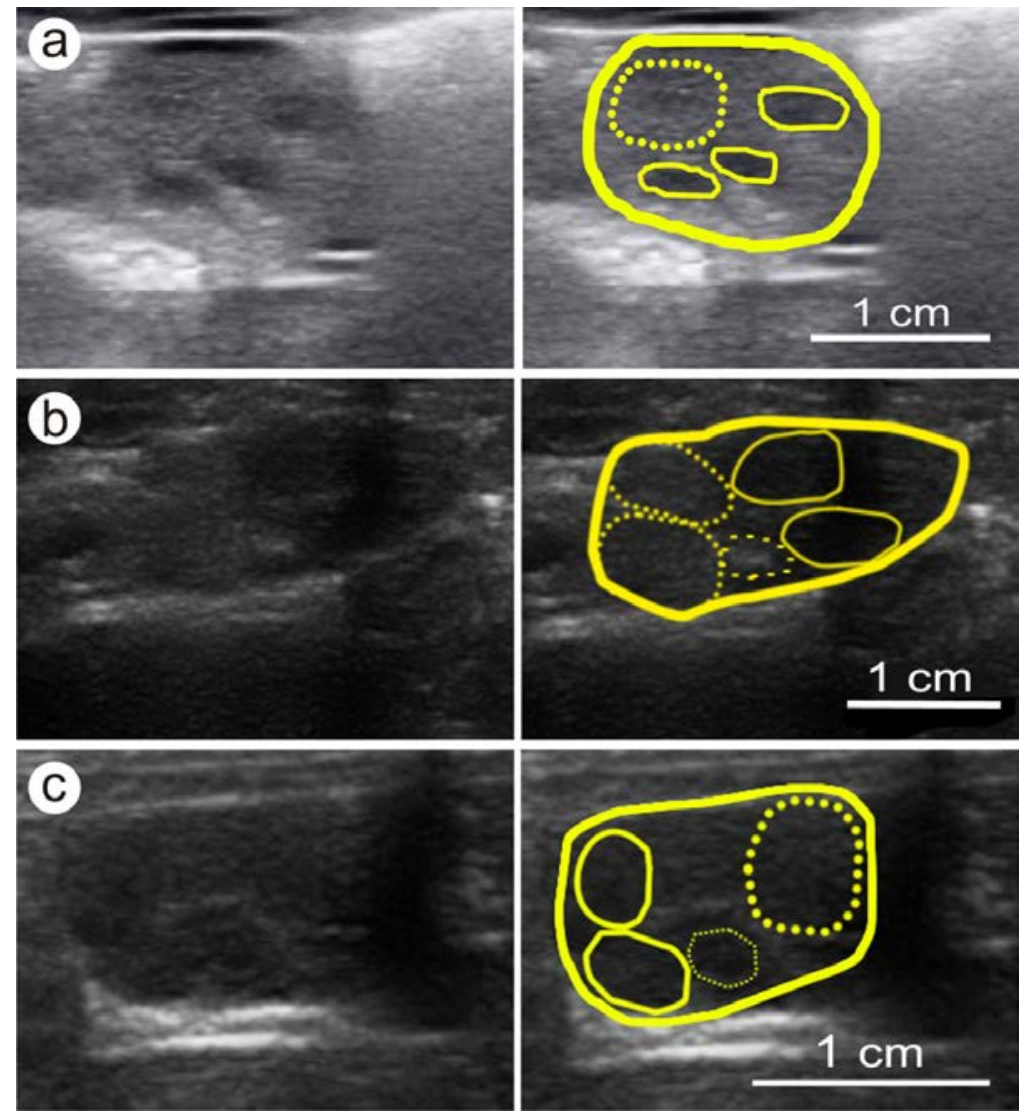

Figure 4. Sonograms of ovaries of the intact queens. The right ovary of intact 1's queen (a) with follicles (thin line) and CL (interrupted thick line); The right ovary of intact 4's queen (b) with follicles and corpus albican (far interrupted line); The ovary of intact 4's queen (c) with follicles, corpus luteum, and corpus rubrum (interrupted thin line). 
Table 4. Diameter size and number of ovaries, follicles, corpus luteums, corpus albicans, and corpus rubrums on the intact queens

\begin{tabular}{|c|c|c|c|c|c|c|}
\hline \multirow{2}{*}{ Parts of ovary } & \multicolumn{5}{|c|}{ Queen ID } & \multirow{2}{*}{ Mean intact } \\
\hline & Intact 1 & Intact 2 & Intact 3 & Intact 4 & Intact 5 & \\
\hline \multicolumn{7}{|c|}{ Diameter (mm); Right ovary } \\
\hline Ovary’s body & 12.67 & 9.17 & 12.34 & 17.32 & 12.03 & \multirow[t]{2}{*}{$12.71 \pm 2.93$} \\
\hline Follicle 1 & 2.35 & - & - & 4.13 & 5.82 & \\
\hline Follicle 2 & 2.21 & - & - & 3.96 & 3.41 & $3.52 \pm 1.26$ \\
\hline Follicle 3 & 2.73 & - & - & - & - & \\
\hline Corpus luteum 1 & 5.90 & 4.13 & 5.05 & 5.79 & 3.93 & \multirow{2}{*}{$4.83 \pm 0.88$} \\
\hline Corpus luteum 2 & - & - & 5.04 & 5.28 & 3.51 & \\
\hline Corpus albican & - & - & - & 3.05 & - & $3.05 \pm 0.00$ \\
\hline Corpus rubrum & - & - & - & - & - & n.a. \\
\hline \multicolumn{7}{|c|}{ Diameter (mm); Left ovary } \\
\hline Ovary’s body & 12.49 & 10.09 & 12.33 & 11.33 & 11.69 & $11.59 \pm 0.96$ \\
\hline Follicle 1 & 3.03 & - & - & 3.38 & 4.00 & \multirow{2}{*}{$3.40 \pm 0.53$} \\
\hline Follicle 2 & 4.09 & - & - & 3.07 & 2.85 & \\
\hline Corpus luteum 1 & 3.12 & 3.64 & 5.04 & 4.36 & 4.38 & \\
\hline Corpus luteum 2 & 3.51 & - & - & - & 4.19 & \\
\hline Corpus luteum 3 & 2.67 & - & - & - & - & $2.95 \pm 1.02$ \\
\hline Corpus luteum 4 & 1.47 & - & - & - & - & \\
\hline Corpus luteum 5 & 2.89 & - & - & - & - & \\
\hline Corpus albican & - & - & - & - & - & n.a. \\
\hline Corpus rubrum & - & - & - & 2.44 & - & $2.44 \pm 0.00$ \\
\hline \multicolumn{7}{|c|}{ Range diameter (mm); Right and left ovary } \\
\hline Ovary’s body & $12.49-12.67$ & $9.17-10.09$ & $12.33-12.34$ & $11.33-17.32$ & $11.69-12.03$ & \\
\hline Follicle & $2.21-4.09$ & - & - & $3.07-4.13$ & $2.85-5.82$ & \\
\hline Corpus luteum & $1.47-5.90$ & $3.64-4.13$ & $5.04-5.05$ & $4.36-5.79$ & $3.51-4.38$ & \\
\hline Corpus albican & - & - & - & 3.05 & - & \\
\hline Corpus rubrum & - & - & - & 2.44 & - & \\
\hline \multicolumn{7}{|c|}{ Number of ovary's parts; right ovary } \\
\hline Follicle & 3 & - & - & 2 & 2 & $2.33 \pm 0.58$ \\
\hline Corpus luteum & 1 & 1 & 2 & 2 & 2 & $1.60 \pm 0.55$ \\
\hline Corpus albican & - & - & - & 1 & - & $1.00 \pm 0.00$ \\
\hline Corpus rubrum & - & - & - & - & - & n.a. \\
\hline \multicolumn{7}{|c|}{ Number of ovary’s parts; left ovary } \\
\hline Follicle & 2 & - & - & 2 & 2 & $2.00 \pm 0.00$ \\
\hline Corpus luteum & 5 & 1 & 1 & 1 & 2 & $2.00 \pm 1.73$ \\
\hline Corpus albican & - & - & - & - & - & n.a. \\
\hline Corpus rubrum & - & - & - & 1 & - & $1.00 \pm 0.00$ \\
\hline \multicolumn{7}{|c|}{ Total number of ovary’s parts; right and left ovary } \\
\hline Follicle & 5 & - & - & 4 & 4 & $4.33 \pm 0.58$ \\
\hline Corpus luteum & 6 & 2 & 3 & 3 & 4 & $3.60 \pm 1.52$ \\
\hline Corpus albican & - & - & - & 1 & - & $1.00 \pm 0.00$ \\
\hline Corpus rubrum & - & - & - & 1 & - & $1.00 \pm 0.00$ \\
\hline
\end{tabular}

n.a.= not available 

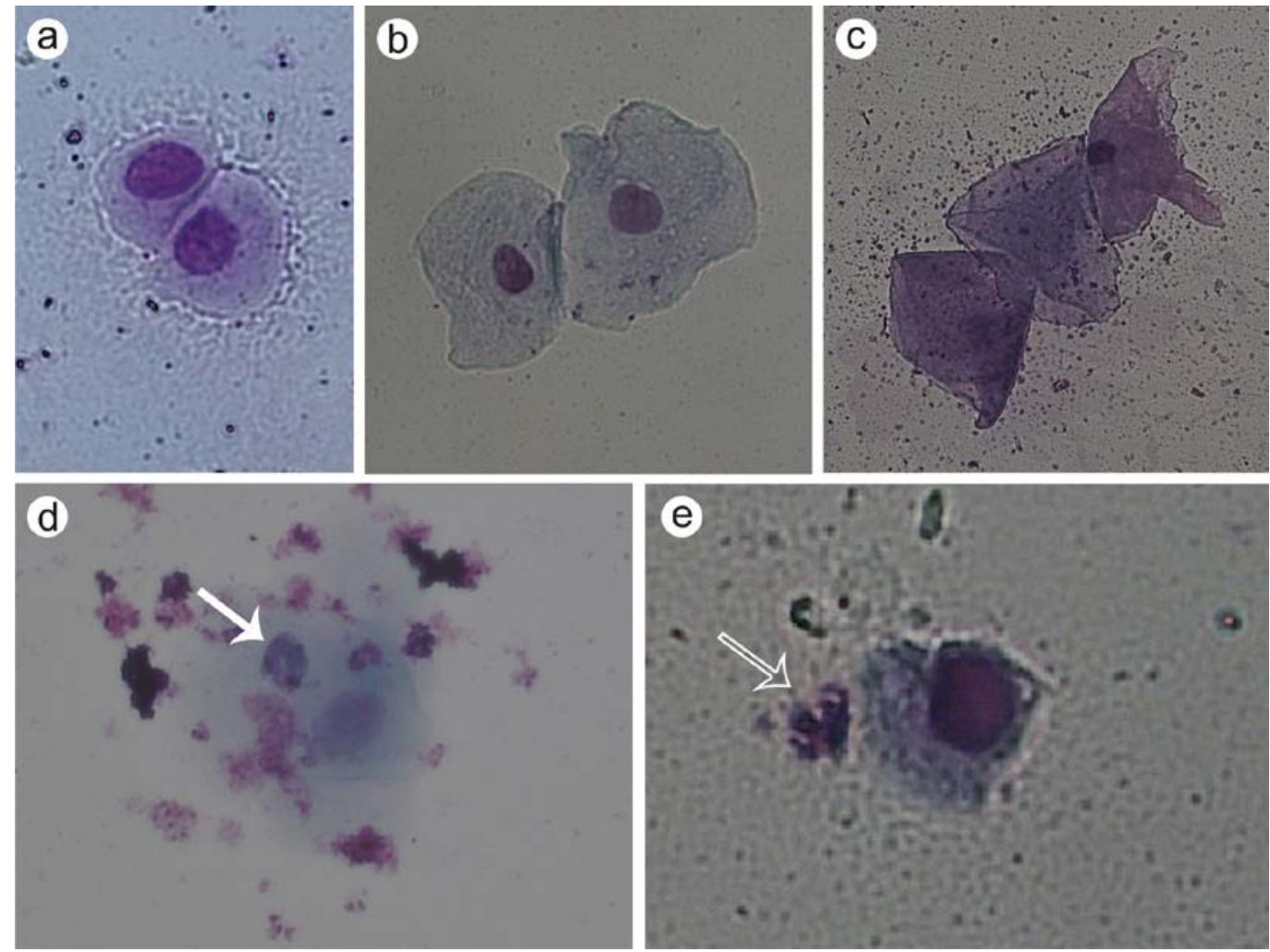

Figure 5. Cells found in vaginal smears. Parabasal (a), intermediate (b), nucleated and un-nucleated superficial (c) vaginal epithelial cells, metestrum cell (white arrow) and neutrophil (empty arrow) (d) seen from the vaginal smears of the queens that used in this study.

Table 5. Number of the queen's vaginal epithelial cell type

\begin{tabular}{lccccc}
\hline \hline \multirow{2}{*}{ Queen ID } & \multicolumn{3}{c}{ Vaginal epithelial cell type } & Metestrum & Neutrophil \\
\cline { 2 - 4 } & Parabasal & Intermediate & Superficial & & 4 \\
\hline Intact 1 & 41 & 44 & 15 & 0 & 0 \\
Intact 2 & 61 & 37 & 2 & 0 & 2 \\
Intact 3 & 18 & 53 & 29 & 0 & 1 \\
Intact 4 & 25 & 57 & 18 & 4 & 0 \\
Intact 5 & 14 & 59 & 27 & 0 & $1.4 \pm 1.7$ \\
Mean intact & $31.8 \pm 19.3$ & $50 \pm 9.3$ & $18.2 \pm 10.8$ & $0.8 \pm 1.8$ & 0 \\
Spayed 1 & 33 & 40 & 27 & 0 & 3 \\
Spayed 2 & 66 & 30 & 4 & 0 & 2 \\
Spayed 3 & 42 & 51 & 7 & 0 & 3 \\
Spayed 4 & 8 & 75 & 17 & 0 & 3 \\
Spayed 5 & 67 & 32 & 1 & 0 & $2.2 \pm 1.3$ \\
Mean spayed & $43.2 \pm 24.7$ & $45.6 \pm 18.4$ & $11.2 \pm 10.7$ & 0 & \\
\hline
\end{tabular}

n.s.=not specific (suspect hormone-insufficiency) 


\section{Diagnoses of estrus state based on vaginal cytology and ultrasonography}

Figure 6 shows the percentage of exfoliate vaginal cells from the totally 10 queens that consist of 5 Intact and 5 Spayed queens. Based on the results showed that 4 of 10 queens diagnosed in metestrus, 3 of 10 in proestrus, 2 of 10 cannot defined the estrus state, and 1 queen diagnoses in anestrus or diestrus (Figure 6a). Further, the diameter of vagina and cervix of all queens has no different between the statuses of estrus (Figure $6 b)$.

Figure 7 shows the diameter of uterus and ovary activity on the sonogram with its relation to estrus status based on vaginal cytology on the 5 intact queens. The uterus body diameter was higher (Figure 7a) on the queens that having ovary with follicles compared to ovary without follicles, only having corpus luteum (Figure 7b).
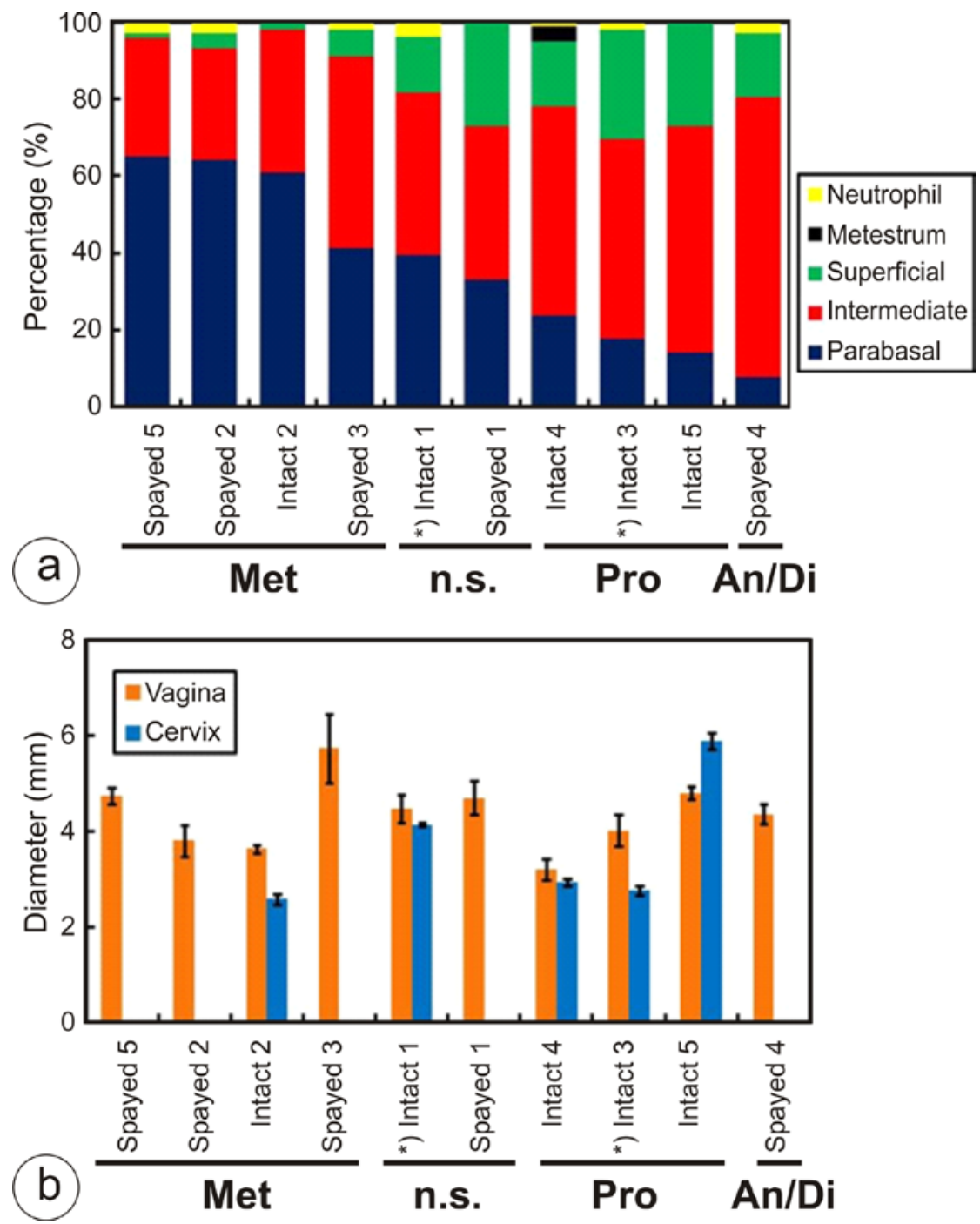

Figure 6. Status of estrus based on percentage of exfoliate cells that found in vaginal smears (a) and diameter of vagina and cervix (b). Note: Met=metestrus, n.s.=not specific, Pro=proestrus, An/Di=anestrus/diestrus, $\left.{ }^{*}\right)=$ multiparous. 

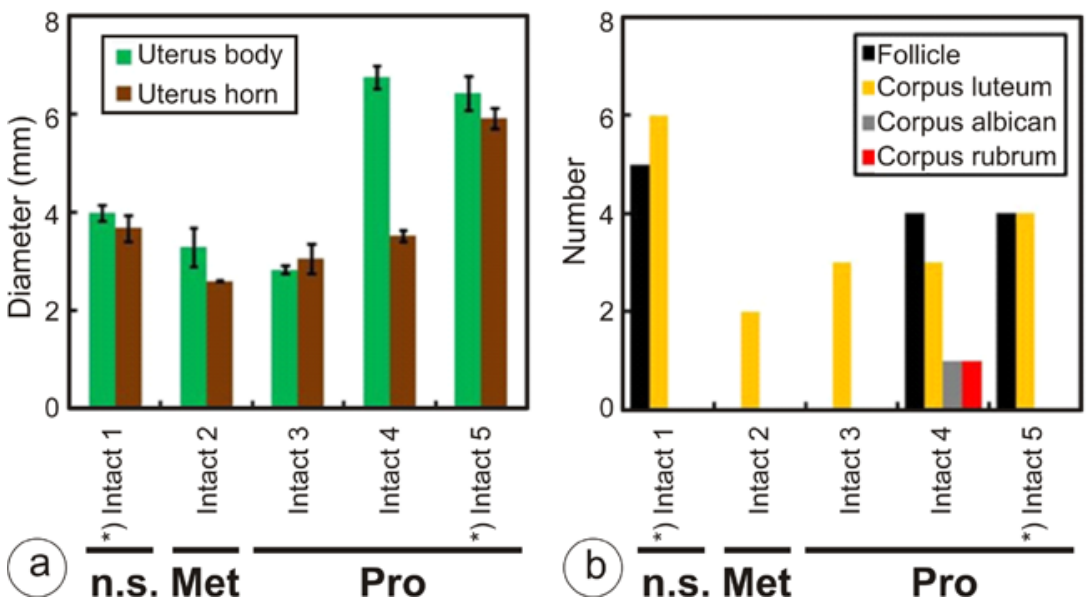

Figure 7. Status of estrus stage based on diameter of uterus (body and horn) (a) and number of follicle, corpus luteum, corpus albican, and corpus rubrum on ovary (b). Note: Met=metestrus, n.s. =not specific, Pro=proestrus, *)= multiparous.

\section{Discussion}

This study shows the complementing diagnosis between ultrasound imaging and vaginal cytology assessment in diagnosis of health reproductive status of Indonesian queens. The procedures were easily to be used in clinical veterinary practices as showed in Figure 1. Even tough, in this study only used 10 queens that consist of intact and spayed (Table 1), this study indicated that ultrasound and vaginal cytology can be used as mutual support in determining the phases of the estrus cycle. In general, the adult queen is a seasonally polyestrus and induced ovulator (Bristol-Gould \& Woodruff 2006). Its ovulation is induced by coitus (Johnston et al. 1996). Coitus-induced ovulation is interpreted as the result of evolution to make sure that the ovulation will only happen after successful coitus, although it does not mean fertilization happens (Goodrowe et al. 1989). When the reproductive organs have reached maturity, the estrus cycle will happen in 5 stages, proestrus, estrus, interestrus, diestrus, and anestrus. The maturity of queen's reproductive organs is influenced by its body weight and photoperiods (Feldman et al. 2014). Queens will sexually mature at the age of 4-12 months, usually between 6 or 8 months (Nutter et al. 2004). This is consistent with the results of this research which shows that 5-month-old queen Intact 5 had already shown ovarial activities by observing its follicles, corpus luteum, and corpus albicans (Table 4, Figure 4).

In sonogram, the shape of the vagina is the main characteristic to differentiate intact queens from the spayed ones. Vagina of spayed queens seems corrugated due to absent of the broad ligament (mesometrium, mesosalphynx, and mesovarium) that fixated and pulled the uterus cranially. The size of the front part of a spayed queen's vagina is larger than intact one due to of the shortening of the spayed queen's vagina, which makes the lumen vagina to be larger (Table 2, Figure 2b). As reported by (Davidson \& Baker 2009), sonogram cervix seems like a thick, hyperechoic pipe in longitudinal view. In queens Intact 2,3 , and 4 which never give birth, the cervix's diameter is smaller than queens Intact 1 and 5 (Table 2). It might be like in human (Sloane 2002), the difference in diameter of cervix in this study can be correlated with the nulliparous condition in queens Intact 2, 3, and 4.

Sonogram of the uterus body is appeared in expands from the end of the cervix to a third of the urine bladder's length cranially (Figure 2c). The wall of uterus is consisted of three layers, which are the mucosa, the muscularis propria, and the serosa (Figure 2). Uterus can be distinguished from the intestines by the difference in appearing its wall layers. The instestinal wall is devided into four layers, which were mucosa, submucosa, muscularis propria, and serosa (Rao \& Wang 2016), and then, the absence of peristaltic contractions, and its relatively straight course, unlike coiled nature the loops of the intestines (Mannion 2008). Endometrium and mesometrium are usually difficult to differentiate in sonogram (Figure 3, Table 3). The lumen of uterus can be seen hyperechoic because of mucus, or hypoechoic to anechoic if there is fluid fill in it (Davidson \& Baker 2009). The outer part, hyperechoic layer is serosa (Gatel et al. 2016). The uterus is seen thicker in proestrus and estrus as the effects of the estrogen and the presence of fluid in it (Davidson \& Baker 2009), as shown in Figure 3b.

The appearance ultrasonographic of ovary is varies based on the estrus stage of the queens (Figure 4, Table 4). Follicles are round shape, filled with fluid, and appear as anechoic in sonogram. The size of follicle in nulliparous queen is between 1-4 mm (Malandain et al. 2011), but in this study the follicle size are ranged between 2.21-5.82 $\mathrm{mm}$. Graafian follicles are the large ovarian follicles with antrum folliculi which will 
ovulate later (Erickson 2000). Sonograms of the largest follicle size which can be reached before ovulation is $3.5 \mathrm{~mm}$ (Malandain et al. 2011), but in this study there are a lot of follicles having larger size. Corpus haemorrhagicum (corpus rubrum) is a follicle that was just ovulated, causing the empty antrum to be filled with blood thus causing it to be seen as a round structure with anechoic centre (Kurjak 1994). Corpus luteum is seen as a thick-walled structure, filled with fluid, and a hypo- or anechoic center (Davidson \& Baker 2009; Mannion 2008). Corpus albicans (Figure $4 a$ ) is seen as a hyperechoic, hyalinated, and convoluted structure whose size is slowly getting smaller (Kurjak 1994).

Vaginal cytology (Figure 1, Figure 5) can be used to determine the stages of queen's estrus cycle (Mills et al. 1979). But according to (Malandain et al. 2011), this method is less precise if used to determine the stages of the ovary's follicle development. The ovary's follicle development is better viewed with ultrasound (Figure 4). However, all the queens that used in this study did not show any behavioral signs of estrus, supported by the ultrasound imaging of ovary (Table 4 and Figure 4) and vaginal cytology results (Table 5) showed that no queens were in estrus stage. Estrus is characterized by dominant amount of superficial vaginal epithelial cells (Mills et al. 1979). Vaginal smear of queens Intact 2 and Spayed 2, 3, 5 showed that those queens were in late metestrus (Table 5), which is characterized by the almost similar amount of parabasal and intermediate epithelial cells with a few superficial epithelial cells (Mills et al. 1979). These three queens (Intact 2, Spayed 2,3 , and 5) were suspected to have ovarian remnant syndrome (ORS). The ORS is a complication that happens because there are some ovarian tissues which were not taken off completely in an ovariohysterectomy procedure in spaying cats (Wallace 1991). The ovarian tissue remnants will undergo adhesion with the omentum, be vascularized and functional again which will then cause the estrus cycle to happen again (DeNardo et al. 2001).

Vaginal cytology of queens Intact 3, 4, and 5 results (Table 5) shows those queens were in proestrus stage which is characterized by the dominant amount of the intermediate epithelial cells and the almost-similar amounts of parabasal and superficial epithelial cells (Mills et al. 1979). The vaginal cytology result of queen Spayed 4 shows that the queen is in anestrus which is characterized by a very-dominant amount of intermediate epithelial cells (Feldman et al. 2014; Mills et al. 1979). The stage of the estrus of queens Intact 1 and Spayed 1 (Table 5) could not be determined based on the categorization of the vaginal cytology results by (Mills et al. 1979). This result's deviation may indicate of hormone-insufficiency or inflamed reproductive tract (vagina) problems (Mills et al. 1979). Neutrophils are normally found a lot in metestrus and a few in anestrus. Bacterial infection may cause neutrophils in large amount (fulfill of microscopic examination view) to be found in estrus and late proestrus (Mills et al. 1979). Neutrophils are usually not found in a queen which is in estrus, except there is an inflammation (vaginitis; fulfill of microscopic examination view). Normally, some bacteria can be found in queen's vaginal cytology assessment. This condition can be said as a pathological one if a high amount of neutrophils is also present (Valenciano \& Cowell 2013). Metestrum cell is a vaginal epithelial cell that contains a neutrophil in its cytoplasm. This cell does not specifically characterize certain stage of estrus and can be found when regular neutrophils are also present (Cowell et al. 2007).

Even tough, reproductive hormone was not evaluated in this study, theoretically, the function of Gonadotropin Releasing Hormone (GnRH) which is generated in hypothalamus in low frequency to stimulate of Follicle Stimulating Hormone (FSH) release and in high frequency to stimulate releasing Luteinizing Hormone (LH) (Heffener \& Danny 2008; Lüking-Jayes et al. 1997). The escalating amount of circulating estrogen hormone and development of follicle are happening in proestrus. The estrogen hormone also affects the start of superficial vaginal epithelial cell escalation in proestrus which can be seen in vaginal cytology of queens Intact 3, 4, and 5 (Table 5) until reaching its highest quantity to other vaginal epithelial cell types when estrus is happening (Rijnberk \& Kooistra 2010). Concentration of estrogen hormone is decreasing when the follicles have reached maturity in a few days after estrus had started. Copulation will stimulate LH release which then will stimulate of ovulation. Mature follicles but non-ovulating will become atretic and decreases the concentration of circulating estrogen hormone. The concentration of circulating progesterone is still low as long as the estrus that happened did not result in ovulation (Engelking \& Rebar 2012).

We also analyze the appearance of the sonogram of vagina and cervix size, and it was not affected by the statuses of estrus (Figure 6). Interestingly, the diameter of the uterus was affected by the ovary activity, where the ovary that owing follicle showed in large diameter compared to corpus luteum (Figure 7). As reported in llama by (Adams et al. 1989) that the uterus tone and shape was affected the ovary activity. Where, the tone and shape of uterus in follicular phase was higher than in luteal phase.

\section{CONCLUSION}

This study has successfully imaged the reproductive organs of queen by ultrasonography and their relationship to the results of vaginal cytology 
assessments. Combination of ultrasound and vaginal cytology diagnostic was able to strengthen the diagnosing the status of estrus in queens.

\section{ACKNOWLEDGMENT}

Authors thank PT Karindo Alkestron that provided the ultrasonography tools (SonoDop S-3X). Authors also thank Nurul Aeni Ayu Lestari for the help in handling and restraining the queens, Prof Dr Drh Mohamad Agus Setiadi for the digital microscope (Olympus CX31 equipped with HDMI \& USB Multioutput HD Camera) that provided in Laboratory of In-vitro Fertilization, and Prof Drh Bambang Purwantara, MSc, $\mathrm{PhD}$ for all the equipments provided in Laboratory of Obstetrics and Gynecology, Division of Reproduction and Obstetrics, Department of Clinic Reproduction and Pathology, Faculty of Veterinary Medicine, Bogor Agricultural University.

\section{REFERENCES}

Adams G, Griffin P, Ginther J. 1989. In situ morphologic dynamics of ovaries, uterus, and cervix in llamas. Biol Reprod. 41:551-558.

Amrozi, Setiawan B. 2011. Sinkronisasi estrus dan pengamatan ultrasonografi pemeriksaan kebuntingan dini pada domba garut (Ovis aries) sebagai standar penentuan umur kebuntingan. J Kedokteran Hewan. 5:73-77.

Bristol-Gould S, Woodruff TK. 2006. Folliculogenesis in the domestic cat (Felis catus). Theriogenology. 66:5-13.

Cowell RL, Tyler RD, Meinkoth JH, DeNicola DB. 2007. Diagnostic cytology and hematology of the dog and cate-book. 3th ed. US: Elsevier Health Sciences. p. 496.

Davidson AP, Baker TW. 2009. Reproductive ultrasound of the bitch and queen. Topics Comp Anim Medic. 24:5563.

DeNardo GA, Becker K, Brown NO, Dobbins S. 2001 Ovarian remnant syndrome: revascularization of freefloating ovarian tissue in the feline abdominal cavity. J Am Anim Hosp Assoc. 37:290-296.

Engelking L, Rebar AH. 2012. Metabolic and endocrine physiology. 3th ed. Boca Raton, Florida (USA): CRC Press.

Erickson GF. 2000. The graafian follicle: A functional definition. In ovulation. New York (USA): Springer. p. 31-48.

Erünal-Maral N, Findik M, Aslan S. 2000. Use of exfoliative cytology for diagnosis of transmissible venereal tumour and controlling the recovery period in the bitch. Dtsch Tierarztl Wochenschr. 107:175-180.
Feldman EC, Nelson RW, Reusch C, Scott-Moncrieff JC. 2014. Canine and feline endocrinology-e-book. 4th ed. US: Elsevier Health Sciences. p. 688.

Gatel L, Gory G, Chalvet-Monfray K, Saunders JH, Rault DN. 2016. Intra-and inter-observer variability in ultrasonographical measurements of the uterus and ovaries in healthy, non-pregnant queens. J Feline Med Surg. 18:110-117.

Goodrowe K, Howard J, Schmidt P, Wildt D. 1989. Reproductive biology of the domestic cat with special reference to endocrinology, sperm function and in-vitro fertilization. J Reprod Fert: Supplement. 39:73-90.

Gunawan S, Yusuf TL, Setiadi MA, Boediono A, Herman R. 2012. Dinamika ovarium selama siklus estrus pada domba Garut. J Veteriner. 13:205-210.

Heffener L, Danny JS. 2008. At a glance sistem reproduksi. 2nd ed. Jakarta (Indones): Erlangga. p. 38.

Johnston SD, Root MV, Olson PN. 1996. Ovarian and testicular function in the domestic cat: clinical management of spontaneous reproductive disease. Anim Reprod Sci. 42:261-274.

Kurjak A. 1994. Ultrasound and the ovary. Boca Raton, Florida (USA): CRC Press.

Lestari NAA, Pertiwi AP, Kombo MP, Tumbelaka LITA, Ulum MF. 2017. Pencitraan ultrasonografi organ hepatobiliari pada Ular Sanca. ARSHI Vet Lett. 1:2930.

Lüking Jayes FC, Britt JH, Esbenshade KL. 1997. Role of gonadotropin-releasing hormone pulse frequency in differential regulation of gonadotropins in the gilt. Biol Reprod. 56:1012-1019.

Malandain E, Rault D, Froment E, Baudon S, Desquilbet L, Begon D, Chastant-Maillard S. 2011. Follicular growth monitoring in the female cat during estrus. Theriogenology. 76:1337-1346.

Mannion P. 2008. Diagnostic ultrasound in small animal practice. Hoboken, New Jersey (USA): John Wiley \& Sons. p. 344.

Mattos M, Simoes-Mattos L, da Silva L. 2003. Vaginal cytology in queens with estrus induced with equine chorionic gonadotrophin. Revista Portuguesa de Ciências Veterinárias. 98:135-138.

Mills JN, Valli V, Lumsden J. 1979. Cyclical changes of vaginal cytology in the cat. Can Vet J. 20:95-101.

Noviana D, Aliambar SH, Ulum MF, Siswandi R. 2012. Diagnosis ultrasonografi pada hewan kecil. Bogor (Indones): IPB Press.

Nutter FB, Levine JF, Stoskopf MK. 2004. Reproductive capacity of free-roaming domestic cats and kitten survival rate. J Am Vet Med Assoc. 225:1399-1402. 
Prawigit W. 2007. Inseminasi buatan dan diagnosa kebuntingan melalui teknik ultrasonografi dan analisa metabolit hormon progesteron pada rusa Timor (Cervus timorensis) hasil sinkronisasi. Bogor (Indones): Bogor Agricultural University.

Rahman AM. 2012. Performa reproduksi kuda pacu Indonesia. Bogor (Indones): Bogor Agricultural University.

Rao J, Wang J. 2016. Intestinal architecture and development. In Regulation of Gastrointestinal Mucosal Growth. San Rafael (Canada): Morgan \& Claypool Life Sciences. p. 132.

Reddy K, Raju K, Rao K, Rao K. 2011. Vaginal cytology, vaginoscopy and progesterone profile: breeding tools in bitches. Iraqi J Vet Sci. 25:51-54.

Rijnberk A, Kooistra HS. 2010. Clinical endocrinology of dogs and cats: An illustrated text. Schlütersche. p. 352.

Santoso S, Amrozi A, Purwatara B, Herdis H. 2014. Gambaran ultrasonografi ovarium kambing kacang yang disinkronisasi dengan hormon prostaglandin f2 alfa (PGF2 $\alpha$ ) dosis tunggal. J Kedokteran Hewan. 8:38-42.
Satria YE, Yusuf TL, Amrozi. 2016. Penentuan waktu optimal kawin berdasarkan ultrasonografi ovarium dengan gejala klinis estrus pada kambing Peranakan Etawa. J Veteriner. 17:64-79.

Sloane E. 2002. Biology of women. 4/Ed. Cengage Learning. p. 656.

Ulum MF, Raudlowi H, Krisnan R. 2017. Ultrasonography of udder parenchymal tissue of Murrah and Swamp buffalo calves. JITV. 22:57-62.

Valenciano AC, Cowell RL. 2013. Cowell and Tyler's diagnostic cytology and hematology of the dog and catE-Book. 4/Ed. US: Elsevier Health Sciences. p. 608.

Wallace MS. 1991. The ovarian remnant syndrome in the bitch and queen. Vet Clin North Am: Small Anim Pract. 21:501-507.

Zora NF. 2014. Identifikasi siklus estrus pada Luwak Jawa (Paradoxurus hermaphroditus) melalui pengamatan gambaran epitel vagina. Bogor (Indones): Bogor Agricultural University. 